\title{
Effect of Various Pretreatments on Germination of Turkish Endemic Achillea gypsicola Hub.-Mor. Species under In Vivo and In Vitro Conditions
}

\author{
Muhammed Akif AÇIKGÖZ ${ }^{1 *}$, Şevket Metin KARA ${ }^{1}$
}

\begin{abstract}
There has been an increasing interest to overcome seed dormancy in medicinal and aromatic plants using various pretreatments. This study was carried out to determine effect of several pretreatments on germination of Turkish endemic Achillea gypsicola Hub.-Mor. species under in vivo and in vitro conditions. The seeds were subjected to three pretreatments as various concentrations of $\mathrm{GA}_{3}$ and $\mathrm{KNO}_{3}$ and 91day cold stratification, with a seven-day interval. In vivo germination test produced no germination in the seeds pre-treated with cold stratification and various concentrations of $\mathrm{GA}_{3}$, whereas $\mathrm{KNO}_{3}$ treatments both in vivo and in vitro explicitly increased germination percentage. Cold stratification showed no inciting effect on germination both in vitro and in vivo conditions. In vitro combined application of $\mathrm{KNO}_{3}$ and $\mathrm{GA}_{3}$ produced higher germination percentages than single applications. The stimulating effect of $\mathrm{KNO}_{3}$ and $\mathrm{GA}_{3}$ on germination percentage increased as the duration of seed immersing in $\mathrm{KNO}_{3}$ increased. The seeds hold in $200 \mu \mathrm{M} \mathrm{KNO}_{3}$ for 48 hours and planted on MS medium supplemented with $2 \mathrm{mg} \mathrm{L}^{-1} \mathrm{GA}_{3}$ showed $100 \%$ germination. In conclusion, this study suggested that combined pre-treatment of $\mathrm{KNO}_{3}$ with $\mathrm{GA}_{3}$ had a great potential in breaking seed dormancy and increasing germination of Turkish endemic Achillea gypsicola Hub.-Mor. species.
\end{abstract}

Keywords: Cold stratification, dormancy, gibberellic acid, potassium nitrate, seed

In Vivo ve In Vitro Koşullar Altında Çeşitli Ön Uygulamaların Türkiye Endemiği Achillea gypsicola Hub.Mor. Türünün Çimlenmesi Üzerine Etkisi

ÖZET: Tıbbi ve aromatik bitkilerde tohum dormansisinin üstesinden gelmek için çeşitli ön uygulamalara karş1 artan bir ilgi vardır. Bu çalışma, çeşitli ön uygulamaların Türkiye endemiği Achillea gypsicola Hub.-Mor. türünün in vivo ve in vitro koşullarda çimlenmesi üzerine etkisini belirlemek amacıyla yapılmıştır. Tohumlar, $\mathrm{GA}_{3}$ ve $\mathrm{KNO}_{3}$ 'ün çeşitli konsantrasyonları ve yedi günlük aralıklarla 91 günlük soğukta katlama gibi üç ön muameleye tabi tutulmuştur. In vivo çimlenme testinde, soğukta katlama ve çeşitli $\mathrm{GA}_{3}$ dozları ile ön muamele edilmiş tohumlarda çimlenme görülmezken, hem in vivo hem de in vitro koşullarda $\mathrm{KNO}_{3}$ uygulamaları çimlenme yüzdesini arttırmıştır. Soğuk katlama, hem in vitro hem de in vivo koşullarda çimlenme üzerinde hiçbir teşvik edici etki göstermemiştir. $\mathrm{KNO}_{3}$ ve $\mathrm{GA}_{3}$ 'ün in vitro koşullarda kombine uygulanması, tek başlarına uygulamalarından daha yüksek çimlenme yüzdeleri üretmiştir. Tohumların $\mathrm{KNO}_{3}$ 'te bekletme süresi arttıkça $\mathrm{KNO}_{3}$ ve $\mathrm{GA}_{3}$ 'ün çimlenme yüzdesi üzerindeki uyarıcı etkisi artmıştır. 48 saat boyunca $200 \mu \mathrm{M} \mathrm{KNO}_{3}$ çözeltisinde bekletilen ve $2 \mathrm{mg} \mathrm{L}^{-1} \mathrm{GA}_{3}$ ile takviye edilmiş MS ortamına ekilen tohumlarda, \%100 çimlenme görülmüştür. Sonuç olarak, bu çalışma $\mathrm{KNO}_{3}$ 'ün $\mathrm{GA}_{3}$ ile birleştirilmiş ön uygulamasının tohum dormansisini kırmada ve endemik Achillea gypsicola Hub.-Mor. türünün çimlenmesini artırmada büyük bir potansiyele sahip olduğunu göstermiştir.

Anahtar Kelimeler: Soğuk katlama, dormansi, giberellik asit, potasyum nitrat, tohum

\footnotetext{
${ }^{1}$ Muhammed Akif AÇIKGÖZ (Orcid ID: 0000-0003-2436-5605), Şevket Metin KARA (Orcid ID: 0000-0001-7755-1394), Department of Field Crops, Faculty of Agriculture, Ordu University, Ordu, Turkey

*Sorumlu Yazar / Corresponding Author: Muhammed Akif AÇIKGÖZ, e-mail: makifacikgoz@ gmail.com

This study was presented orally at the "2nd International Conference on Advances in Natural and Applied Sciences düzenlen held on 1821 April 2017 in Antalya Turkey

Geliş tarihi / Received: 10.01.2019

Kabul tarihi / Accepted: 30.06 .2019
} 


\section{INTRODUCTION}

Turkey, located at the convergence point of three floristic regions, is known as one of the most biologically diverse countries in the temperate zone. Its plant diversity is manifested by the presence of over 12000 plant species, around $30 \%$ of which are endemic (Uludag et al., 2017). Medicinal and aromatic plants belonging to Lamiaceae, Apiaceae and Asteraceae, with high rate of endemism, represent an important component of this biodiversity endowment of the country. The potential benefits of medicinal and aromatic plants are largely accounted for naturally occurring bioactive compounds, called secondary metabolites. The genus of Achillea as known "civanperçemi" in Turkish, a member of Asteraceae family, is represented by 59 species in Turkey, 31 of which are endemic (Tabanca et al., 2016; Demirci et al., 2018). The genus of Achillea has been proven to have an important secondary metabolite; the terpene camphor which has long been used in medicine and cosmetics industry due to its antimicrobial and anti-carcinogenic properties (Abdel-Rahman et al., 2015; Almadiy et al., 2016). Some previous studies have revealed that camphor content showed a wide range of variation in the species of Achillea genus, changing between $0.6 \%$ and $32.7 \%$ (Sampietro et al., 2016; Ghasemi, 2017). The main source of camphor is the species of Cinnamomum camphora Sieb. known as camphor tree and growing wild in the Far East countries, contains around 68\% camphor compound (Frizzo et al., 2000; Zuccarini, 2009). Achillea gypsicola Hub.Mor., an endemic yarrow species of Turkey, has $40 \%$ camphor content, although it has an herbaceous growth habit (Baser, 2016). With its relatively short growing period, it is apparent from these results that, Achillea gypsicola is a very good source in terms of camphor in the plants kingdom including woody plants. Within their native environments, endemic plants have been exposed to several serious threat and, in consequence of this, the production of certain secondary metabolites with sufficient amount and quality form the plants grown in wild are inhibited (Paunescu, 2009). Furthermore, growing medicinal and aromatic plants with conventional techniques and producing secondary metabolites are of time consuming and rather costly. Plant cell cultures are of considerable importance and commonly used in production of these valuable phytochemicals of certain quality standards, without seasonal limitations (Bourgaud et al., 2001; Abdin et al., 2007). The first milestone in plant cell cultures providing rapid, easy and mass production of valuable secondary metabolites is to overcome seed dormancy and obtain a good level of germination in vitro. It has been a wellknown fact that the seeds of certain medicinal and aromatic plant species have some degree of dormancy, easily germinating within their native environments, but failing to show good germination under laboratory conditions (Gupta, 2003; Zare et al., 2011). The need, thus, is apparent to develop some methods breaking dormancy in seeds and promoting germination, particularly in vitro condition. Foremost among these applications are such processes as subjecting seeds to cold stratification and keeping them in hormones and osmotic solutions (Bhardwaj et al., 2016). In the scientific literature, there has been no information concerning the potential seed dormancy problems and a study presenting the effect of seed pretreatments on germination of Achillea gypsicola species. Furthermore, a study we carried out with Achillea gypsicola indicated that the seeds exhibited some degree of dormancy and the present study will be the first attempt to overcome seed dormancy in this species (Acikgoz, 2017). In view of these points, this study was aimed to determine the effect of some pretreatments such as immersing seeds in gibberellic acid and potassium nitrate solutions and cold stratification on germination of Turkish endemic Achillea gypsicola Hub.-Mor. species both in vivo and in vitro conditions. 


\section{MATERIALS AND METHODS}

The seeds of Turkish endemic Achillea gypsicola species collected from its natural habitat were used in the study. Achillea gypsicola plants were detected on the right-side hills at the $26^{\text {th }}$ and $47^{\text {th }}$ kilometers of Corum-Iskilip (latitude $40^{\circ} 73 \mathrm{~N}$, longitude $34^{\circ} 47^{\prime} \mathrm{E}$ ) road and the plant samples of both above- and below-ground organs were taken for species diagnosis on June 7, 2017. A herbarium of the plant samples was kept at normal room temperatures until species diagnosis. Species diagnosis was carried out by Assist. Prof. Dr. Sevda TÜRKİŞ, a member of the Science Education Department, Education Faculty of Ordu University. Voucher plant specimens were kept in the herbarium at Field Crops Department of Agricultural Faculty, Ordu University. The seeds were collected from the representing samples of the whole plants found at the region on August 13, 2017 and properly cleaned seeds were kept in jars with cork stoppers until they were subjected to germination tests.

\section{Seed surface sterilization}

The seeds were immersed at first in $70 \%$ alcohol for 10-15 sec for pre-sterilization and then rinsed with distilled water. Further, the seeds were surface sterilized by shaking in $25 \%$ sodium hypo-chloride $(13 \% \mathrm{NaOCl})$ for 45 minutes and rinsed with distilled water.

\section{In vivo germination tests}

In this part of germination test, the seeds were subjected to three pretreatments as;

a) Gibberellic acid $\left(\mathrm{GA}_{3}\right)$ : The seeds were kept in solutions containing various $\mathrm{GA}_{3}$ concentrations $(25,50,75,100,200,400$ and $800 \mathrm{ppm}$ ) for 24 hours, along with the control (water).

b) Cold stratification: The seeds were exposed to 13 cold stratifications with seven days interval in a period of 91 days.

c) Potassium nitrate $\left(\mathrm{KNO}_{3}\right)$ : The seeds were soaked in solutions containing 100 and 200 $\mu \mathrm{M} \mathrm{KNO}{ }_{3}$ for several hours $(12,24,36$ and 48 hours), along with the control (water).
The germination tests were carried out with eight replications. Fifty seeds were placed in two layers of filter paper in petri dishes of $18 \mathrm{~cm}$ and the petri dishes were stored at 16/8 hours light/dark conditions at $25^{\circ} \mathrm{C}$ for 14 days.

\section{In vitro germination tests}

The germination tests were repeated 6 times with petri dishes containing eight seeds each. The $\mathrm{pH}$ of the culture media of MS (Murashige and Skoog, 1962) was adjusted to 5.8. The petri dishes were stored at 16/8 hours light/dark conditions at $25^{\circ} \mathrm{C}$. A number of in vitro germination tests were carried out using $\mathrm{GA}_{3}, \mathrm{KNO}_{3}$ and cold stratification as seed pretreatments:

a) $\mathrm{GA}_{3}$ application to MS media; the seeds were planted in MS media including various concentrations $(0,0.1,0.5,1,2,3,5,7,9,11$ and $15 \mathrm{mg} \mathrm{L}^{-1}$ ) of $\mathrm{GA}_{3}$.

b) Immersing seeds in $\mathrm{GA}_{3}$; the seeds were planted in MS media with several concentrations $\left(0,0.5,1\right.$ and $\left.2 \mathrm{mg} \mathrm{L}^{-1}\right)$ of $\mathrm{GA}_{3}$, after keeping them in solutions containing various levels $(0,25,50,75,100,200,400$ and $800 \mathrm{ppm})$ of $\mathrm{GA}_{3}$ for 24 hours.

c) Cold stratifications; the seeds exposed to 13 cold stratifications at $2{ }^{\circ} \mathrm{C}$, in a period of 91 days with a seven-day interval, were planted in MS media having different concentrations $(0$, $0.5,1$ and $\left.2 \mathrm{mg} \mathrm{L}^{-1}\right)$ of $\mathrm{GA}_{3}$.

d) Potassium nitrate $\left(\mathrm{KNO}_{3}\right)$ and gibberellic acid $\left(\mathrm{GA}_{3}\right)$ applications; the seeds were planted in MS media with four concentrations $(0,0.5,1$ and $2 \mathrm{mg} \mathrm{L}^{-1}$ ) of $\mathrm{GA}_{3}$ after soaking in $\mathrm{KNO}_{3}$ solutions (100 and $200 \mu \mathrm{M})$ and in water (the control) for 12, 24, 36 and 48 hours.

The seeds, both in vivo and in vitro, with 2 $\mathrm{mm}$ of radicle were considered as germinated. Germination percentage was calculated as the ratio of the number of daily germinated seeds to the total number of seeds tested. Germination percentages were arcsine transformed and then data were subjected to an ANOVA. The assumptions of data normality and homogeneity 
of variance were tested with the KolmogorovSmirnov test and the Levene's test (Steel and Torrie, 1980). Means compared with Tukey's HSD test and all calculations were performed with Minitab 17 statistical software.

\section{RESULTS AND DISCUSSION}

\section{In vivo germination tests}

In vivo germination tests revealed that no germination occurred with gibberellic acid $\left(\mathrm{GA}_{3}\right)$ and cold stratification, but in vivo potassium nitrate applications stimulated seed germination explicitly (Figure 1). Increasing concentrations of $\mathrm{KNO}_{3}$ resulted in a significant increase in germination percentage, with no germination in the control solution (water). The interaction effect of $\mathrm{KNO}_{3}$ concentrations $\mathrm{x}$ immersing hours was found to be non-significant, that is, the stimulating effect of potassium nitrate concentrations on germination increased depending on immersing hours of the seeds in $\mathrm{KNO}_{3}$ solution. The maximum germination percentages recorded in the seeds kept in $200 \mu \mathrm{M}$ $\mathrm{KNO}_{3}$ for 12, 24, 36 and 48 hours were found to be $10 \%, 12 \%, 27 \%$ and $33 \%$, respectively. These results suggest that the stimulating effect of $\mathrm{KNO}_{3}$ concentrations on germination percentage increases as the duration of seed immersing increases. The previous studies also indicated that $\mathrm{KNO}_{3}$ applications played an effective role in breaking seed dormancy and increasing germination (Fariman et al., 2011; Gupta et al., 2011; Gashi et al., 2012).

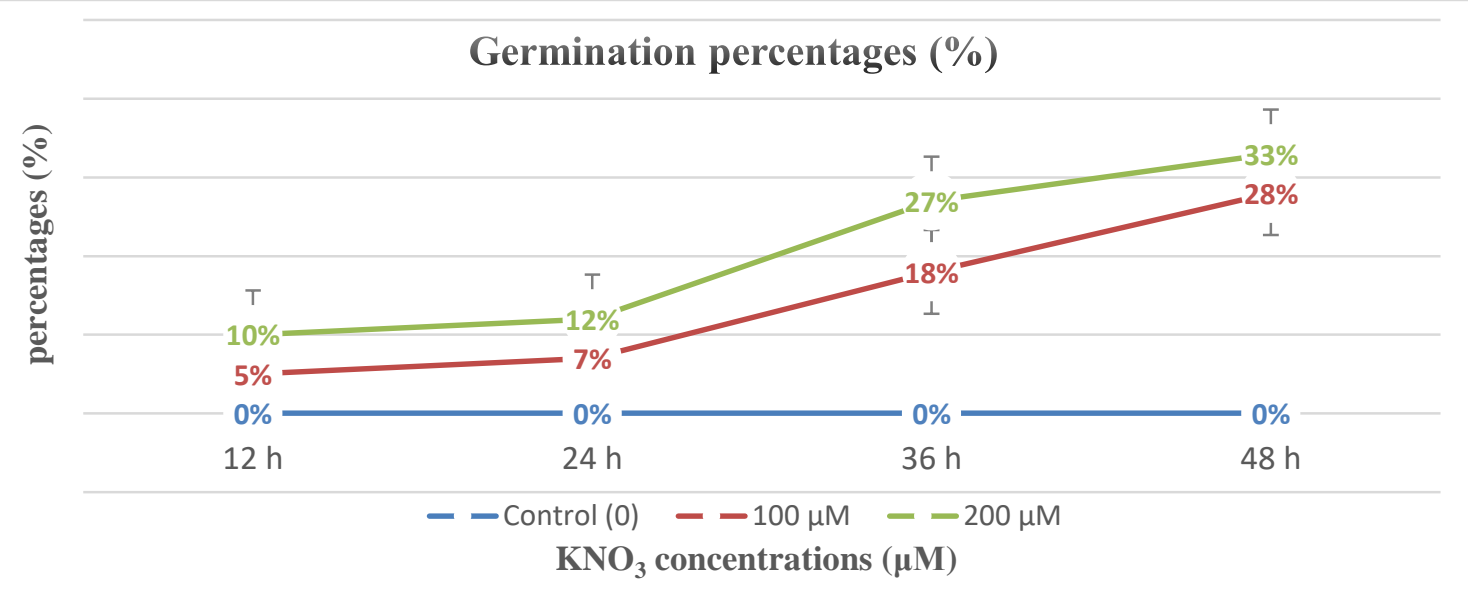

Figure 1. In vivo germination percentages $(\%)$ of the seeds kept in $\mathrm{KNO}_{3}$ solutions of different concentrations for different hours

\section{In vitro germination tests}

In the first in vitro germination test, adding increasing concentrations of $\mathrm{GA}_{3}$ to MS media resulted in a significant increase in germination percentage, as compared to the control. Germination percentages obtained from $\mathrm{GA}_{3}$ treatments ranged from $14 \%$ to $19 \%$, with no germination in the control treatment (Figure 2). With the first three $\mathrm{GA}_{3}$ concentrations, germination percentage linearly increased from $17 \%$ to $19 \%$, but decreased to $14 \%$ with additional concentrations.
The second in vitro germination test was consisted of two stages; at first, the seeds were kept in $\mathrm{GA}_{3}$ solutions of several concentrations for 24 hours and then they were planted in MS media containing three levels of $\mathrm{GA}_{3}$ solution, along with the control. $\mathrm{GA}_{3}$ application of increasing levels to MS media produced a significant and regular increase in germination percentage, with the highest obtained in media containing the highest $(2 \mathrm{mg} / \mathrm{l}) \mathrm{GA}_{3}$ level (Figure $3)$. Immersing seeds in increasing concentrations of $\mathrm{GA}_{3}$ up to $200 \mathrm{ppm}$, before planting to $\mathrm{MS}$ 
media, resulted in a constant increase in germination percentage up to $27 \%$, with almost no changes in additional $\mathrm{GA}_{3}$ concentrations. The germination percentage increased as $\mathrm{GA}_{3}$ concentrations added to MS medium increased, irrespective of $\mathrm{GA}_{3}$ concentration of immersing solution, suggesting that two-way interaction of $\mathrm{GA}_{3}$ concentrations MS media and immersing solution.

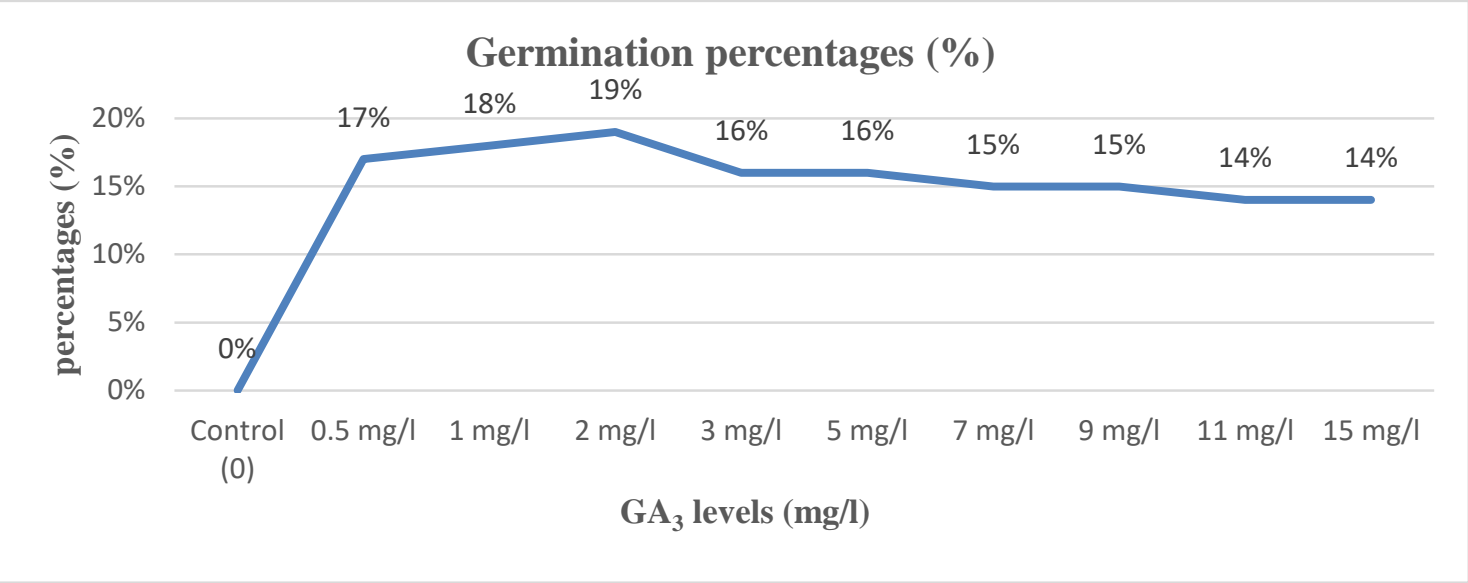

Figure 2. Germination percentages (\%) of the seeds planted in MS media with various levels of $\mathrm{GA}_{3}$

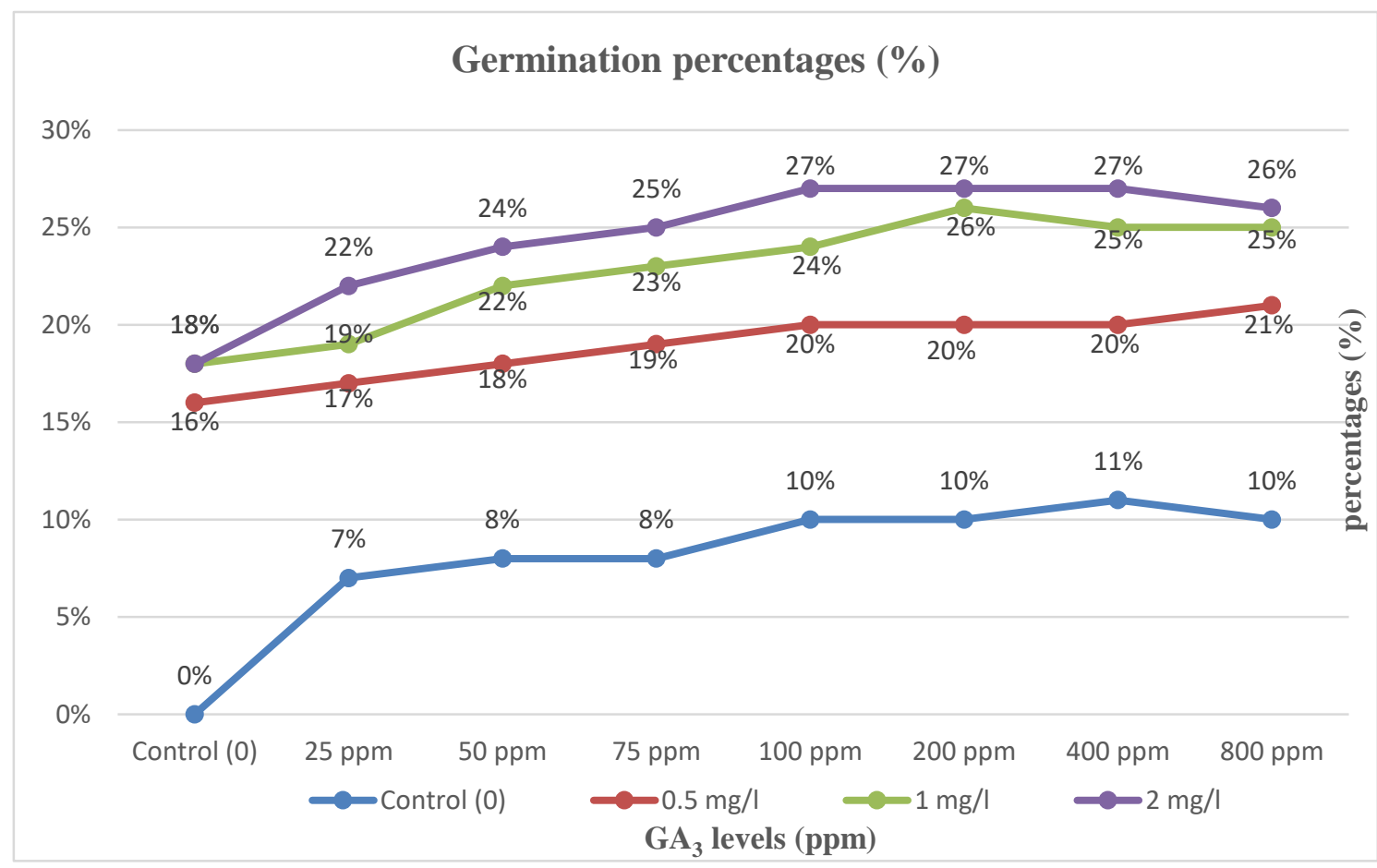

Figure 3. Germination percentages (\%) of the seeds planted in MS media with several $\mathrm{GA}_{3}$ levels, after keeping in $\mathrm{GA}_{3}$ solutions of various concentrations for 24 hours

Several studies reported that certain in vitro pre-treatments such as soaking seeds in $\mathrm{GA}_{3}$ solution for some times produced good results in breaking primer seed dormancy and reducing the time taken for germination (Warakagoda and Subasinghe, 2014; Kadi et al., 2015; Elhindi et al., 2016). It was recorded that, dipping the seeds of C. fenestratum in $2250 \mathrm{mg} \mathrm{L}^{-1} \mathrm{GA}_{3}$ solution for 
$24 \mathrm{~h}$ reduced the time taken for germination by removing inhibitory chemicals, facilitating embryo growth and reducing inherent $\mathrm{ABA} / \mathrm{GA}_{3}$ ratio (Warakagoda and Subasinghe, 2014). There was no germination in the seeds exposed to 13 cold stratifications at $2{ }^{\circ} \mathrm{C}$, in a period of 91 days with a seven-day interval, before planting to MS media including several concentrations $(0,0.5,1$ and $2 \mathrm{mg} \mathrm{L}^{-1}$ ) of $\mathrm{GA}_{3}$. On the other hand, combined application of potassium nitrate and gibberellic acid significantly enhanced seed germination, ranging from 2.08 to $100 \%$ (Table 1). In combined application, the seeds were dipped in $\mathrm{KNO}_{3}$ solutions of 100 and $200 \mu \mathrm{M}$ and in water (the control) for 12, 24, 36 and 48 hours before planting in MS media with $0.5,1$ and $2 \mathrm{mg}$ $\mathrm{L}^{-1}$ concentrations of $\mathrm{GA}_{3}$, and the control. The germination percentages of the seeds steadily increased in accordance with the concentration of $\mathrm{KNO}_{3}$ solution, incubation time in $\mathrm{KNO}_{3}$ solution and $\mathrm{GA}_{3}$ concentrations added to the growth medium. Three-way interaction of $\mathrm{KNO}_{3}$ and $\mathrm{GA}_{3}$ concentrations and immersing hours was found to be significant, suggesting that the effect of addition of increasing concentrations of $\mathrm{GA}_{3}$ to MS media varied depending on $\mathrm{KNO}_{3}$ concentrations and immersing hours of the seeds in $\mathrm{KNO}_{3}$ solutions, and/or vice versa.

Table 1. Germination percentages* $(\%)$ of the seeds, stored in $\mathrm{KNO}_{3}$ solutions of different concentrations for different hours, planted in media including $\mathrm{GA}_{3}$ of different concentrations.

\begin{tabular}{|c|c|c|c|c|c|}
\hline \multirow{2}{*}{$\mathrm{KNO}_{3} \mu \mathrm{M}$} & \multirow{2}{*}{$\mathbf{G A}_{3} \mathrm{mg} \mathrm{L}^{-1}$} & \multicolumn{4}{|c|}{ Immersing hours in $\mathrm{KNO}_{3}$} \\
\hline & & $12 \mathrm{~h}$ & $24 \mathrm{~h}$ & $36 \mathrm{~h}$ & $48 \mathrm{~h}$ \\
\hline \multirow{4}{*}{$\mathbf{0}$} & $\mathbf{0}$ & $0.00 \pm 0.001$ & $12.50 \pm 2.081$ & $12.50 \pm 0.001 \mathrm{j}$ & $29.17 \pm 2.64 \mathrm{~g}$ \\
\hline & 0.5 & $0.00 \pm 0.001$ & $14.58 \pm 2.641$ & $16.67 \pm 0.001 \mathrm{j}$ & $52.08 \pm 4.17 \mathrm{f}$ \\
\hline & 1 & $2.08 \pm 2.08 \mathrm{k}$ & $22.92 \pm 3.23 \mathrm{~h}$ & $25.00 \pm 3.84 \mathrm{~h}$ & $52.08 \pm 2.64 \mathrm{c}$ \\
\hline & 2 & $6.25 \pm 2.80 \mathrm{j}$ & $31.25 \pm 2.08 \mathrm{~g}$ & $35.42 \pm 2.80 \mathrm{~g}$ & $54.17 \pm 3.23 b$ \\
\hline \multirow{4}{*}{100} & $\mathbf{0}$ & $4.17 \pm 2.64 \mathrm{jk}$ & $18.75 \pm 2.64 \mathrm{~h}$ & $20.83 \pm 2.801$ & $81.25 \pm 3.84 b$ \\
\hline & 0.5 & $4.17 \pm 2.64 \mathrm{jk}$ & $20.83 \pm 4.17 \mathrm{~h}$ & $29.17 \pm 2.64 \mathrm{~g}$ & $89.58 \pm 2.08 b$ \\
\hline & 1 & $8.33 \pm 2.64 \mathrm{j}$ & $29.17 \pm 2.64 \mathrm{~g}$ & $33.33 \pm 2.64 \mathrm{~g}$ & $89.58 \pm 2.08 \mathrm{c}$ \\
\hline & 2 & $8.33 \pm 2.64 j$ & $35.42 \pm 3.84 \mathrm{~g}$ & $52.08 \pm 3.84 \mathrm{f}$ & $89.58 \pm 2.08 \mathrm{~b}$ \\
\hline \multirow{4}{*}{200} & $\mathbf{0}$ & $4.17 \pm 2.64 \mathrm{jk}$ & $16.67 \pm 3.84 \mathrm{~h}$ & $22.92 \pm 2.641$ & $85.42 \pm 4.27 \mathrm{~d}$ \\
\hline & 0.5 & $10.42 \pm 2.08 \mathrm{j}$ & $27.08 \pm 3.84 \mathrm{gh}$ & $35.42 \pm 3.84 \mathrm{~g}$ & $85.42 \pm 2.08 \mathrm{~b}$ \\
\hline & 1 & $18.75 \pm 2.801$ & $56.25 \pm 2.80 \mathrm{f}$ & $70.83 \pm 4.17 \mathrm{de}$ & $89.58 \pm 2.08 \mathrm{c}$ \\
\hline & 2 & $25.00 \pm 3.23 \mathrm{~h}$ & $68.75 \pm 2.80 \mathrm{e}$ & $81.25 \pm 2.80 \mathrm{~d}$ & $100.00 \pm 0.00 \mathrm{a}$ \\
\hline
\end{tabular}

Mean \pm Standard Error of Mean; Means with similar letter in \% 5 level of Tukey test are not significant.

Among the three treatments, immersing hour appeared to be the most effective factor on seed germination, suggesting that effects of $\mathrm{KNO}_{3}$ and $\mathrm{GA}_{3}$ concentrations were predominantly determined by the duration of immersing hour. For example, the seeds pretreated just in water for 48 hours showed $29.17 \%$ germination, higher than those of seeds treated with different concentrations of $\mathrm{KNO}_{3}$ and $\mathrm{GA}_{3}$ for 12 hours. The seeds exposed to pre-treatments of 100 and $200 \mu \mathrm{M} \mathrm{KNO}_{3}$ solutions for 48 hours had much higher germination percentage than the other applications. The highest germination $(100 \%)$ was obtained from the combined application of immersing seed in $200 \mu \mathrm{M} \mathrm{KNO}_{3}$ solution for 48 hours and adding $2 \mathrm{mg} \mathrm{L}^{-1} \mathrm{GA}_{3}$ to MS medium. In order to break seed dormancy and increase germination, a number studies have been carried out using $\mathrm{GA}_{3}, \mathrm{KNO}_{3}$, cold stratification and acid scarification alone or together (Nadjafi et al., 2006; Cirak et al., 2007; Fariman et al., 2011; Elhindi et al., 2016). It is well documented that $\mathrm{GA}_{3}$ enhances the biosynthesis of starchdigesting enzyme $\alpha$ amylase and this is assumed 
to be an initially essential process of seed germination (McCrate et al., 1981; Kolumbina et al., 2006). Furthermore, it was concluded that using certain chemical stimulants as seed pretreatments could result in a reduction in seed growth inhibitors such as abscisic acid, one of the reasons for the positive effects of potassium nitrate on breaking dormancy and promoting germination. The effect of $\mathrm{KNO}_{3}$ was discovered when it was proven that Knop's Solution encouraged germination of some plant species. The beneficial effect of $\mathrm{KNO}_{3}$ was explained by the nitrate reductase enzyme activity in the production of nitrite/nitric oxide, which acted to remove dormancy and promote faster germination (Delian and Lagunovschi-Luchian, 2015). Most of the studies in the literature showed that germination percentages were higher with combined applications of these pretreatments, indicating a very good consistency with the results of the present study. When cold stratification and $\mathrm{GA}_{3}$ was individually applied, the germination percentage was at most $68 \%$, but when these two tested together, the germination percentage reached up to $91.66 \%$ (Zare et al., 2011). In a study with Echinacea purpurea L. seeds, using $\mathrm{GA}_{3}$ and cold stratification alone gave $32 \%$ germination percentage as the highest, but with combined application the highest percentage was found to be $90.02 \%$ (Zahed et al., 2015). Gibberellic acid has been reported to induce an increase on the effect of certain germination promotors such as $\mathrm{HNO}_{3}, \mathrm{H}_{2} \mathrm{SO}_{4}$, chilling and soaking with water in Ferula gummosa Boiss and Teucrium polium L. species, traditional medicinal plants in Iran (Nadjafi et al., 2006). The response to acid scarification and water soaking in both species was stronger when $\mathrm{GA}_{3}$ was combined, indicating an apparent synergistic response. It was reported that highest germination percentage was $32 \%$ when $\mathrm{KNO}_{3}$ and cold stratification used separately, but with combined application germination percentage significantly increased up to $76 \%$ (Raisi et al.,
2013). In a study with Ramonda serbica Panc. and Ramonda nathalie Panc. endemic species of Balkan Peninsula, the highest germination percentage was obtained in the seeds treated 1000 ppm $\mathrm{GA}_{3}+0.3 \% \mathrm{KNO}_{3}(92.26 \%)$ and $500 \mathrm{ppm}$ $\mathrm{GA}_{3}+0.2 \% \mathrm{KNO}_{3}(91.81 \%)$, compared to the seeds $(9.26 \%)$ without pretreatment (Gashi et al., 2012). Delian and Lagunovschi-Luchian (2015) stated that potassium phosphate and ascorbic acid could be employed as alternative carrot seed priming treatments to provide rapid, highest germination percentage and early vigorous seedling growth under saline stress conditions. The effects of germination stimulants on breaking seed dormancy and increasing germination can be independent of each other, additive, and interactive (Chuanren et al., 2004).

\section{CONCLUSION}

In vivo germination test resulted in no germination in Achillea gypsicola seeds pretreated with $\mathrm{GA}_{3}$ and cold stratification, while $\mathrm{KNO}_{3}$ applications both in vivo and in vitro highly promoted germination percentage. Cold stratification at $2{ }^{\circ} \mathrm{C}$ had no inciting effect on seed germination both in vitro and in vivo conditions. In vitro combined applications of both $\mathrm{KNO}_{3}$ and $\mathrm{GA}_{3}$ produced higher germination percentages than separate applications. In vitro germination percentage of Achillea gypsicola seeds pretreated with $200 \mu \mathrm{M} \mathrm{KNO} 3$ for 48 hours and planted on MS medium supplemented with $2 \mathrm{mg}$ $\mathrm{L}^{-1} \mathrm{GA}_{3}$ reached to $100 \%$. In conclusion, the present study has established a highly effective strategy for breaking seed dormancy and increasing seed germination of Achillea gypsicola through combined application of $\mathrm{KNO}_{3}$ and $\mathrm{GA}_{3}$ solutions.

\section{ACKNOWLEDGEMENTS}

We are thankful to Scientific Research Projects Unit (BAP) of Ordu University for providing support to this research, with the number of AR-1644 BAP Project. 


\section{REFERENCES}

Abdel-Rahman RF, Algasoumi S, El-Desoky A, Soliman G, Pare G, Hegazy ME, 2015. Evaluation of the anti-inflammatory, analgesic and anti-ulcerogenic potentials of Achillea fragrantissima. South African Journal of Botany, 98: 122-127.

Abdin MZ, Zhu Y, Tan B, Bay B, Liu C, 2007. Enhancing bioactive molecules in medicinal plants. Natural Products, 3: 4557.

Acikgoz MA, 2017. The determination of secondary metabolite production potential with callus culture in the species of Achillea gypsicola. Ordu University, Institute of Science, PhD Thesis (Printed).

Almadiy AA, Nenaah GE, Al-Assiuty BA, Moussa EA, Mira NM, 2016. Chemical composition and antibacterial activity of essential oils and major fractions of four Achillea species and their nanoemulsions against foodborne bacteria. LWT-Food Science and Technology, 69: 529-537.

Baser KHC, 2016. Essential oils of Achillea species of Turkey. Natural Volatiles \& Essential Oils, 3: 1-14.

Bhardwaj AK, Kapoor S, Naryal A, Bhardwaj P, Warghat AR, Kumar B, Chaurasia OP, 2016. Effect of various dormancy breaking treatments on seed germination, seedling growth and seed vigor of medicinal plants. Tropical Plant Research, 3: 508-516.

Bourgaud F, Gravot A, Milesi S, Gontier E, 2001. Production of plant secondary metabolites, a historical perspective. Plant Science, 5: 839-851.

Chuanren D, Bouchu V, Vangian L, Jing C, Lie L, Huan NZ, 2004. Effect of chemical and physical factors to improve the germination rate of Echinacea angustifolia seeds. Colloids and Surfaces B: Biointerfaces, 37: 101-105.
Cirak C, Kevseroğlu K, Ayan AK, 2007. Breaking of seed dormancy in a Turkish endemic Hypericum species: Hypericum aviculariifolium depilatum var. depilatum by light and some pre-soaking treatments. Journal of Arid Environments, 68: 159-164.

Delian E, Lagunovschi-Luchian V, 2015. Germination and vigour of primed Daucus carota L. seeds under saline stress conditions. Romanian Biotechnological Letters, 20: 10833- 10840.

Demirci B, Başer KHC, Aytaç Z, Khan SI, Jacob MR, Tabanca N, 2018. Comparative study of three Achillea essential oils from eastern part of Turkey and their biological activities. Records of Natural Products, 12: 195-200.

Elhindi KM, Dewir YH, Asrar AW, Abdel-Salam E, El-Din AS, Ali M, 2016. Improvement of seed germination in three medicinal plant species by plant growth regulators. Horticulture Science, 51: 887-891.

Fariman ZK, Azizi M, Noori S, 2011. Seed germination and dormancy breaking techniques for Echinacea purpurea L. Journal of Biological and Environmental Sciences, 5: 7-10.

Frizzo CD, Santos AC, Paraul N, Serafini LA, Dellacassa E, Lorenzo D, Moyna P, 2000. Essential oils of camphor tree (Cinnamomum camphora Nees and Eberm) cultivated in southern Brazil. Journal of Brazilian Archives of Biology and Technology, 43: 313-316.

Gashi B, Abdullai K, Mata V, Konglika E, 2012. Effect of gibberellic acid and potassium nitrate on seed germination of the resurrection plants Ramonda serbica and Ramonda nathaliae. African Journal of Biotechnology, 11: 4537-4542.

Ghasemi PA, 2017. Chemical composition of the essential oils from the leaves and flowers of two Achillea species from Iran. Journal of Essential Oil Bearing Plants, 20: 205-214. 
Gupta SM, Pandey P, Grover A, Ahmed Z, 2011. Breaking seed dormancy in Hippophae salicifolia, a high value medicinal plant. Physiology and Molecular Biology of Plants, 17: 403-406.

Gupta V, 2003. Seed germination and dormancy breaking techniques for indigenous medicinal and aromatic plants. Journal of Medicinal and Aromatic Plants Science, 25: 402-407.

Kadi K, Alaoui MM, Hamli S, Addad D, Dib D, Yahia A, 2015. Seed germination and dormancy breaking techniques for white henbane (Hyoscyamus albus L.). Advances in Environmental Biology, 9: 17-22.

Kolumbina M, Blesing M, Mares DJ, 2006. $\alpha$ Amylase and programmed cell death in aleurone of ripening wheat grains. Journal of Experimental Botany, 57: 877-885.

McCrate AJ, Nielsen MT, Paulsen GM, Heyne EG, 1981. Gibberellic acid effects on germination and $\alpha$ amylase activity of winter wheats. Euphytica, 30: 875-880.

Murashige T, Skoog F, 1962. A revised medium for rapid growth and bioassays with tobacco tissue cultures. Plant Physiology, 15: 473497.

Nadjafi F, Bannayan M, Tabrizi L, Rastgoo M, 2006. Seed germination and dormancy breaking techniques for Ferula gummosa and Teucrium polium. Journal of Arid Environments, 64: 542-547.

Paunescu A, 2009. Biotechnology for Endangered Plant Conservation: A Critical Overview. Romanian Biotechnological Letters, 14: 4095-4103.

Raisi A, Kalat SN, Darban AS, 2013. The study effects of stratification, temperature and potassium nitrate on seed dormancy breaking. World Applied Sciences Journal, 21, 379-383.
Sampietro DA, Lizarraga EF, Ibatayev ZA, Omarova AB, Suleimen YM, Catalan CA, 2016. Chemical composition and antimicrobial activity of essential oils from Acantholippia deserticola, Artemisia proceriformis, Achillea micrantha and Libanotis buchtormensis against phytopathogenic bacteria and fungi. Natural Product Research, 30: 1950-1955.

Steel RGD, Torrie JH, 1980. Principles and procedures of statistics, second edition. McGraw-Hill Publishing Company, New York, USA.

Tabanca N, Demirci B, Aytaç Z, Başer KHC, 2016. Chemical composition of Achillea schischkinii Sosn. an endemic species from Turkey. National Volatiles \& Essential Oils, 3: 24-28.

Uludag A, Aksoy N, Yazlik A, Arslan ZF, Yazmis E, Uremis I, Brundu G, 2017. Alien flora of Turkey: checklist, taxonomic composition and ecological attributes. NeoBiota, 35: 61-85.

Warakagoda PS, Subasinghe S, 2014. In vitro Seed Germination of Coscinium fenestratum (Gaertn.). Annual Research \& Review in Biology, 4: 3549-3565.

Zahed SY, Ramin AA, Baninasab B, 2015. Effect of gibberellic acid, stratification and salinity on seed germination of Echinacea purpurea cv. Magnus. Herba Polonica, 61: 13-22.

Zare AR, Solouki M, Omidi M, Irvani N, Abasabadi AO, Nezad NM, 2011. Effect of various treatments on seed germination and dormancy breaking in Ferula assa foetida L. (Asafetida), a threatened medicinal herb. Trakia Journal of Sciences, 9: 57-61.

Zuccarini P, 2009. Camphor: Risks and benefits of a widely used natural product. Journal of Applied Science of Environmental Management, 2: 69-74. 